\title{
INTERJECTION “ONDEH” IN MINANGKABAU LANGUAGE AS MARKERS OF ATTITUDES AND EMOTIONS
}

\author{
Widya \\ Program Studi Pendidikan Bahasa Inggris, \\ Fakultas Bahasa dan Seni, Universitas Indraprasta PGRI \\ Pos-el: widya.center@gmail.com
}

\begin{abstract}
This study aimed to find out whether the interjection "ondeh" with a certain pitch contour carries signals of different attitudes and emotions and to describe the tone contour of interjection "ondeh" with certain attitudes and emotions. This research combines qualitative and quantitative methods. Qualitative method is applied in description and analysis, while quantitative method is only used to calculate the frequency of the tone and perception test results. The data was obtained through the process of sound recording of several informants who are native speakers of Minangkabau language. The findings show that the interjection "ondeh" with a certain intonation contours carries signals of different attitudes and emotions. Those attitudes and emotions are feeling amazed, shocked and upset. Interjection "ondeh" of amazed shows a significant difference in duration between syllable on and deh. The duration of the syllable deh tends to be much longer than the duration of the syllable on. The same thing is also found in interjection "ondeh" showing upset. However, speakers tend not to pronounce the sound [on] so that the sounds heard are just [deh] when they are upset. Furthermore, the emotion of surprised is shown with tone on syllable on which tends to be higher when compared to the one of amazed and upset. Finally, context of the sentence is also very influential in determining signal of certain attitudes and emotions.
\end{abstract}

Key words: prosodic features, interjection, emotion

\begin{abstract}
ABSTRAK
Penelitian ini bertujan untuk untuk mencari tau apakah interjeksi ondeh dengan kontur nada tertentu membawa sinyal sikap dan emosi yang berbeda dan untuk mendeskripsikan kontur nada interjeksi ondeh dengan sinyal sikap dan emosi tertentu. Penelitian ini mengombinasikan metode kualitatif dan kuantitatif. Metode kualitatif dipakai dalam deskripsi dan analisis sedangkan metode kuantitatif hanya digunakan untuk menghitung frekuensi nada dan hasil uji persepsi.Sumber data penelitian ini diperoleh melalui proses perekaman suara beberapa orang informan yang merupakan penutur asli bahasa Minangkabau. Hasil penelitian menunjukkan bahwa ungkapan ondeh dengan kontur intonasi tertentu membawa sinyal sikap dan emosi yang berbeda. Sinyal sikap dan emosi itu berupa perasaan kagum, kaget, dan kesal. Interjeksi ondeh yang membawa sinyal emosi kagum memperlihatkan perbedaan
\end{abstract}


durasi yang cukup signifikan antara silabe on dan deh. Durasi silabel deh cenderung jauh lebih panjang daripada durasi silabel on. Sama dengan sinyal emosi kagum, pada emosi kesal ciri sinyal emosi pada interjeksi ondeh ditunjukkan oleh durasi silabe deh yang cenderung panjang. Namun, pada emosi kesal penutur cenderung untuk tidak mengucapkan bunyi [on] sehingga yang terdengar hanya bunyi [deh]. Selanjutnya, sinyal emosi kaget ditunjukkan dengan nada pada silabel on yang cenderung tinggi apabila dibandingkan dengan silabel on pada emosi kagum dan kesal. Konteks kalimat juga sangat berpengaruh dalam menentukan sinyal sikap dan emosi tertentu.

Kata kunci: fitur prosodi, interjeksi, emosi

\section{PENDAHULUAN}

Kridalaksana (2008: 130) menyatakan bahwa komunikasi merupakan penyampaian amanat dari pengirim ke penerima melalui sebuah saluran. Saluran tersebut dapat berupa tulisan (dalam komunikasi tertulis) dan bunyi bahasa (dalam tuturan). Komunikasi antara pengirim dan penerima, secara lisan terbangun dalam tiga perangkat, yaitu penghasilan, penyampaian, dan penerimaan bunyi bahasa. Ketiga perangkat tersebut dalam ilmu linguistik ditelaah melalui studi fonetik, yakni fonetik artikulatoris, fonetik akustis, dan fonetik auditoris. Pernyataan tersebut secara jelas direfleksikan melalui definisi berikut "fonetik adalah ilmu yang menyelidiki penghasilan, penyampaian, dan penerimaan bunyi bahasa" (Kridalaksana, 2008: 63). Oleh karena itu, penelitian ini akan difokuskan pada fonetik akustis dan fitur fonologis yang dibawa bunyi bahasa serta persepsi yang ditimbulkan terhadap bunyi bahasa.

Setiap ujaran tidak hanya mengandung unsur-unsur segmental berupa bunyibunyi konsonan dan bunyi-bunyi vokal. Ujaran tersebut menghasilkan getaran bunyi yang mengubah tekanan udara yang ada di dalam ruangan sehingga partikel udara tersebut membentuk gelombang bunyi (Rahyono, 2005: 42). Gelombang bunyi tersebut membawa fitur fonologis, seperti intensitas, nada, dan durasi. Fitur fonologis yang dimaksud disebut juga fitur prosodi (suprasegmentalfeature).Crystal (1997) mendefinisikan suprasegmental sebagai kualitas suara yang menyertai bunyi yang dibedakan dari segmental. Ciri suprasegmental yang berupa tekanan (stress), jangka (length), nada (intonation) memberikan aspek tambahan pada bunyi yang berlaku bukan hanya pada satu unsur segmental, tetapi juga pada satu suku kata (Ladefoged, 2006).

Sering arti penting sebuah ujaran tidak ditentukan oleh apa yang diujarkan oleh penutur, tetapi mengujarkannya. Sebuah ujaran dengan pilihan kata yang persis sama, akan menimbulkan efek yang sangat berbeda diakibatkan oleh karakteristik akustik yang berbeda. Contoh, apabila seorang guru mengujarkan kalimat "Sandi, jangan ribut. Kamu akan mengganggu teman-temanmu yang sedang belajar" dengan tekanan dan intonasi yang tinggi untuk mengekspresikan keterkejutan dan kemarahannya, akan menimbulkan efek yang lebih kuat terhadap si pendengar daripada diujarkan dengan tekanan dan intonasi yang tidak tinggi. Dengan kata lain, 
makna sebuah ujaran sangat dipengaruhi oleh emosi yang dilibatkan saat ujaran tersebut dihasilkan. Emosi tersebut diwujudkan dalam fitur-fitur prosodi yang menyertai sebuah ujaran.

Uraian di atas sesuai dengan Rietveld dan Heuven (dalam Witteman 2014) yang mengungkapkan bahwa fitur prosodi dalam tuturan membawa empat fungsi yang berbeda, yaitu; (1) Fungsi leksikal yaitufitur prosodi yang keberadaannya dapat memengaruhi makna satuan bahasa. Fitur yang membawa fungsi tersebut dapat berupa tekanan dan nada. (2) Fungsi demarkatif, yaitu fitur prosodi yang berperan sebagai pemarkah batas satuan bahasa. Fitur yang dimaksud dapat berupa jeda, tempo, dan tekanan di awal dan di akhir satuan.(3) Fungsi informatif, yaitu fitur prosodi yang berperan memberi penegasan atau penerangan pada tuturan yang diujarkan. Fitur yang dimaksud dapat berupa aksen dan pola intonasi. (4) Penanda sikap dan emosi. Melalui fitur prosodi dapat diketahui sikap dan kondisi emosional penutur. Fitur ini diketahui melalui perubahan durasi, tinggi nada, dan intonasi.

Nada secara tidak langsung dipengaruhi oleh faktor biologis, fisik, dan emosi penutur (Waugh dan Schooneveld, 1980: 1-3). Penutur akan kehilangan keelastisitasan artikulatornya apabila penutur tersebut berada dalam kondisi lemah. Hal ini berdampak pada kualitas nada yang semakin rendah. Pernyataan tersebut merupakan refleksi faktor biologis yang turut memengaruhi tinggi rendahnya nada.

Perubahan nada-nada yang dihasilkan dalam pertuturan membentuk kontur nada. Kontur nada tersebut merupakan gambaran intonasi (Rahyono, 2005: 44). Intonasi adalah "pola perubahan nada yang dihasilkan pembicara pada waktu mengucapkan ujaran atau bagian-bagiannya" (Kridalaksana, 2008: 85). Pola intonasi tersebut dapat dihitung dengan ukuran semiton. Semiton adalah satuan ukuran ketinggian nada. Rahyono (2005: 44) menyatakan bahwa satu semiton sama dengan jarak ketinggian nada antara satu bilah piano dengan bilah lainnya. Dapat disimpulkan nada dan intonasi adalah dua elemen yang tidak terpisahkan.

Salah satu kelas kata yang pemaknaannya sangat dipengaruhi oleh fitur prosodi adalah interjeksi atau kata seru. Interjeksi adalah suatu reaksi sesaat, yang merupakan dampak dari situasi ekstra-linguistik. Menurut Kridalaksana (2008: 95) interjeksi merupakan bentuk yang tidak dapat diberi afiks dan tidak memiliki dukungan sintaksis dengan bentuk lain, dan yang dipakai untuk mengungkapkan perasaan; biasanya muncul pada awal ujaran. Ungkapan tersebut merupakan rangkaian perbuatan yang berujung pada reaksi emosional terhadap kejadian di luar bahasa.

Interjeksi dalam sebuah kalimat dapat ditemukan di awal, di akhir, dan di tengah kalimat. Interjeksi yang ditemukan di awal kalimat disebut prajeksi. Ungkapan wow! adalah contoh interjeksi yang berada di awal kalimat. Beberapa interjeksi dituturkan di belakang kalimat. Bentuk seperti itu disebut posjeksi. Kata cape deh! 
yang menandakan sinyal sikap dan emosi kesal adalah contoh posjeksi yang sering dituturkan dalam bahasa nonformal. Interjeksi dapat juga disisipkan ditengah ujaran. Misalnya kata ah pada kalimat "Kisah hidupnya, ah, sungguh menyedihkan!"

Interjeksi dapat dijumpai disetiap bahasa, termasuk dalam bahasa Minangkabau, bahasa yang dipelihara dan dipakai sebagai bahasa pertama dalam berkomunikasi sehari-hari oleh masyarakat pendukungnya yang tinggal di daerah Sumatera Barat dan daerah perantauan seperti masyarakat Mukomuko di Bengkulu, Natal dan Barus di Sumatera Utara, Tapak Tuan di Aceh, Bangkinang, Pekan Baru dan Taluk di Riau, bahkan di Negeri Sembilan Malaysia. (Moussay, 1998)

Moussay (1998: 102) mengatakan untuk mengungkapkan perasaan atau penilaian afektif digunakan ujaran seruan. Lebih lanjut Moussay mengatakan, ujaran tersebut memiliki dua bentuk yaitu bentuk lengkap dan bentuk tidak lengkap. Bentuk lengkap dibangun berdasarkan model yang sama dengan ujran interogatif dan menggunakan partikel tak takrif yang sama sebagai ekslamatif. Hanya intonasinya yang berbeda, yang di sini ditandai dengan tanda seru di akhir ujaran, sedangkan bentuk tak lengkap ialah bentuk yang dipersingkat menjadi intejeksi saja. Bentuk itu dapat dipahami dalam suatu konteks dan tanda seru diletakkan langsung setelah interjeksi yang lazim diletakkan di awal ujaran. Interjeksi itu termasuk onomatope, teriakan, kutukan, panggilan ataupun umpatan. Semua interjeksi itu dianggap sebagai kata tugas. Lebih jauh lagi Syafyahya dkk. (2015) mengungkapkan bahwa dari bentuk lengkap dan tidak lengkap ujaran seruan ini, dapat dikelompokan atas 4 watak kato, yaitu kato mancari kawan ' kata mencari teman', kato mancari lawan 'kata mencari lawan', kato indak bakawan 'kata tidak berteman', dankato indak balawan 'kata tidak dilawan'. Di samping itu, ujaran seruan dalam bahasa Minangkabau mempunyai variasi leksikal dan variasi penggunaan. Variasi leksikal terjadi karena perbedaan daerah penggunaan, sedangkan variasi penggunaan terjadi karena tujuan penggunaannya. Variasi leksikal juga dapat terjadi pada daerah yang sama atau satu daerah. Begitu juga halnya dengan variasi penggunaannya.

Salah satu bentuk interjeksi yang penggunaannya sangat produktif dalam bahasa Minangkabau adalah interjeksi ondeh.Ondeh dapat dituturkan secara berbeda bergantung pada aspek fonetis yang mengikuti ungkapan, sikap, dan kondisi emosional penutur. Aspek fonetis tersebut berupa fitur suprasegmental, seperti nada, intonasi, tekanan, dan durasi. Sinyal sikap dan emosi dalam ungkapan tersebut tercermin dalam dua fitur suprasegmental yang dianggap sangat menonjol dan memberi pengaruh, yaitu tinggi nada dan durasi.

Berdasarkan uraian di atas, penelitian ini bertujuan untuk mencari tahu apakah interjeksi ondeh dengan kontur nada tertentu membawa sinyal sikap dan emosi yang berbeda dan untuk mendeskripsikan kontur nada interjeksi ondeh dengan sinyal sikap dan emosi tertentu.Seperti yang telah diungkapkan sebelumnya, penelitian mengenai interjeksi dalam bahasa Minangkabau sudah pernah 
dilaksanakan, tetapi berfokus pada bentuk-bentuk interjeksi. Penelitian ini melihat interjeksi, khususunya interjeksi ondeh, dari sudut pandang fonologi. Penelitian difokuskan pada fitur prosodi yang membawa fungsi sebagai penanda atau sikap dan emosi penutur. Diharapkan penelitian ini dapat menunjukkan bahwa interjeksi ondeh dengan kontur nada tertentu membawa sinyal sikap dan emosi yang berbeda dan hasilnya dapat mendeskripsikan kontur nada ungkapan ondeh dengan sinyal sikap dan emosi tertentu.

\section{METODE PENELITIAN DAN DATA}

Penelitian ini mengombinasikan metode kualitatif dan kuantitatif. Metode kualitatif melibatkan deskripsi dan analisis sedangkan metode kuantitatif hanya digunakan untuk menghitung frekuensi nada dan hasil uji persepsi.Dalam penelitian ini penulis melewati beberapa tahap hingga dapat membuat kesimpulan. Tahap-tahap tersebut adalah sebagai berikut.

1. Perekaman data. Sumber data penelitian ini diperoleh melalui proses perekaman suara beberapa orang informan yang merupakan penutur asli bahasa Minangkabau. Suara informan direkam dalam bentuk data komputerdengan format WAV. Alat perekam yang digunakan adalah perangkat komputer pada laboratorium fonetik.

1. Pengolahan DataRekaman.Hasil perekamandiolah dengan program PRATT yang diciptakan oleh Paul Boersma dan David Weenink.Melalui program tersebut data bunyi bahasa diolah dalam enam proses;(a) ekstraksi bunyi (dalam format WAV), (b) segmentasi kata (TextGrid), (c) manipulasi nada dan intonasi (manipulation), (d) ekstraksi hasil manipulasi (PitchTier), (e) Penyalinan data (nada, intonasi, dan durasi) dalam PRATT Picture atau close copy, dan (f) pemindahan data kedalam formatMicrosoft Word.

2. Uji Screening. Tahap uji screening dilakukan untuk memilih data suara terbaik, memiliki kejelasan, dan ketepatan sinyal sikap dan emosi. Dalam penelitian ini tahap uji screening tidak melibatkan responden. Penulis sendiri yang melakukan uji screening terhadap data yang didapat. Penulis memilih satu dari tiga hasil rekaman untuk setiap sinyal emosi. Penulis menggunakan intuisi penulis, yang juga merupakan penutur asli bahasa Minangkabau, untuk menilai mana data yang layak dijadikan sample data.

3. Eksperimen dan modifikasi kontur nada. Tahap ini dilakukan untuk menentukan kontur standar untuk interjeksi ondeh pembawa sinyal emosi tertentu.

4. Uji persepsi. Uji persepsi dilakukan terhadap tiga orang penutur asli bahasa Minangkabau. Responden diminta untuk memilih dan menilai suara rekaman hasil modifikasi yang sesuai dengan sinyal emosi tertentu, dalam hal ini emosi kagum, kaget, dan kesal.

\section{Membuat kesimpulan}

Dari hasil perekaman sumber data, diperoleh dua hasil rekaman yang menunjukkan sinyal emosi kagum, kaget, dan kesal. Kemudian satu datum dipilih untuk dianalisis. Data yang didapat disegmentasi, dimanipulasi, dan disalin pola intonasinya (close copy). Pemanipulasian nada dilakukan pada nada yang dinilai 
mencurigakan, tidak sesuai dengan kontur nada, dan tidak mengalami perubahan saat dimanipulasi. Berikut gambar kontur yang dimaksud.

\section{Sinyal Emosi Kagum}

Grafik 1 Manipulasi 1 (0101)

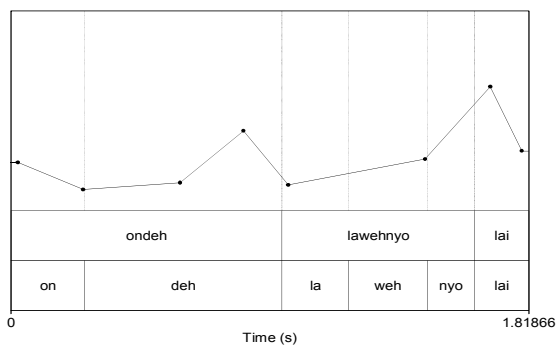

Grafik 2 Manipulasi 2 (0102)

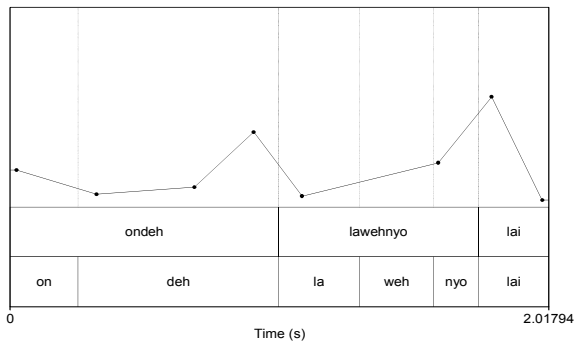

Grafik 3 Manipulasi 3 (0103)

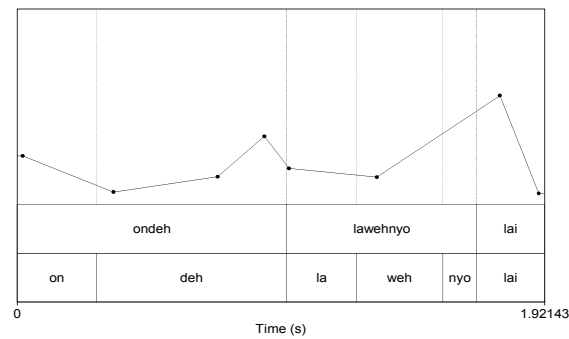

Dari ketiga grafik hasil manipulasi di atas, kemudian dilakukan penghitungan rerata frekuensi dari titik dana interjeksi ondeh.Grafik 1 dan 3 menunjukkan kesamaan pola kontur nada. Pada awal ujaran yaitu pada silabel pertama on rerata tinggi titik nada ialah $241.573 \mathrm{~Hz}$. Kemudian cenderung turun pada awal silabel ke dua dengan rerata $192.439 \mathrm{~Hz}$. Alir nada pada silabe kedua kemudian kembali naik hingga mencapai frekuensi maksimal pada bunyi [e] dengan rerata $291.525 \mathrm{~Hz}$.

Durasi silabel pertama dan silabel kedua interjeksi ondeh juga berbeda pada setiap grafik. Silabel deh memiliki durasi yang jauh lebih panjang dari durasi silabel 
on yaitu dengan rerata perbedaan $0.445095 \mathrm{~s}$. Perbedaan panjang durasi silabe on dan deh inilah yang menjadi ciri kata ondeh sebagai pembawa sinyal emosi kagum.

\section{Sinyal Sikap dan Emosi Kaget}

Sama dengan yang dilakukan pada sinyal emosi kagum, sinyal emosi kaget dianalisis dengan menyegmentasi, memanipulasi, dan menyalin pola intonasi (close copy). Berikut adalah grafik yang menujukkan kontur nada dan durasi interjeksi ondeh

Grafik 4 Manipulasi 1 (0201)

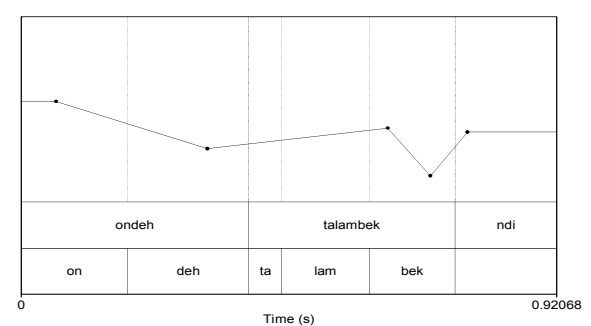

Grafik 6 Manipulasi 3 (0203)

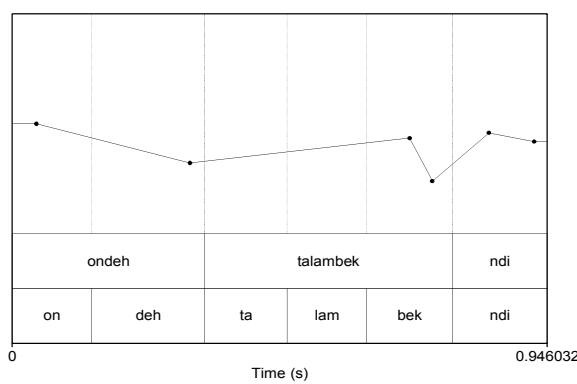

Kontur nada pada ketiga grafik relatif sama. Nada cenderung tinggi pada silabel pertama dengan rerata $307.365 \mathrm{~Hz}$. Selanjutnya alir nada akan turun dengan cukup signifikan dengan rerata $275.222 \mathrm{~Hz}$. Penurunan nada dari silabel pertama ke silabel kedua ini yang menjadi ciri interjeksi ondeh pembawa sinyal emosi kaget.

\section{Sinyal Sikap dan Emosi Kesal}

Setelah melalui proses manipulasi, close copyhasil manipulasi nada sinyal emosi kesal sebagai berikut

Grafik 7 Manipulasi 1 (0301)

Gafik 8 Manipulasi 2 (0302) 

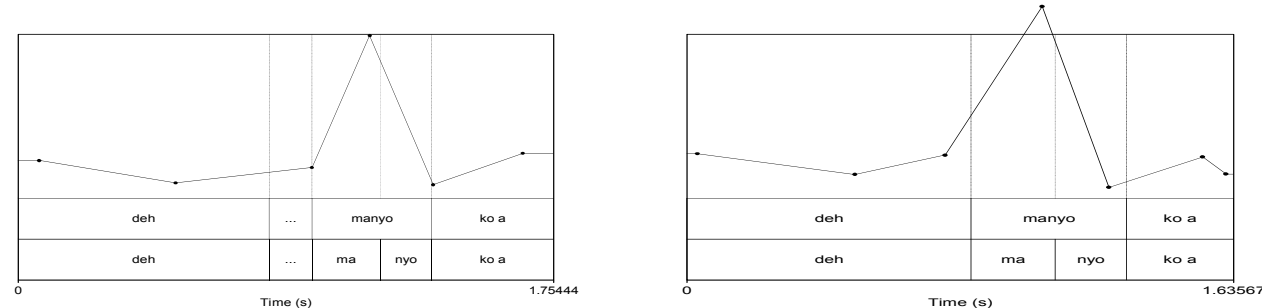

Grafik 9 Manipulasi 3 (0303)

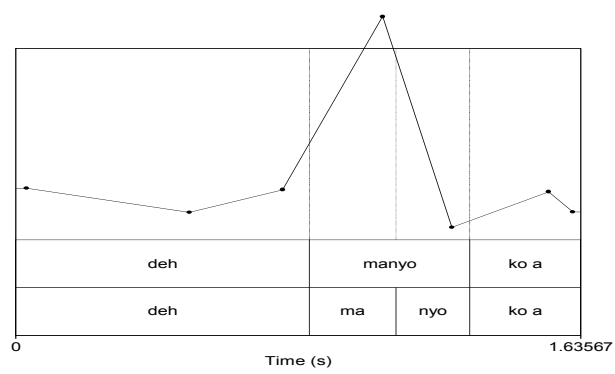

Untuk sinyal emosi kesal, grafik 8 dan 9 memperlihatkan persamaan kontur nada dan agak sedikit berbeda dengan kontur nada pada grafik 7. Alir nada pada sinyal emosi kesal hampir sama dengan emosi kagum, hanya saja pada emosi kagum terjadi reduksi bunyi [on] sehingga yang terdengar hanya bunyi [deh]. Rerata durasi silbel deh pada emosi ini ialah $0.867258 \mathrm{~s}$. Nada cenderung tinggi di awal ujaran, kemudian turun pada bunyi [e].

Interjeksi ondeh yang membawa sinyal emosi memperlihatkan kontur nada yang berbeda di setiap sinyal emosi. Simpulan yang dapat ditarik dari grafik kontur nada dan durasi di atas adalah (1) interjeksi ondeh yang membawa sinyal emosi kagum memperlihatkan perbedaan durasi yang cukup signifikan antara silabe on dan deh. Durasi silabel deh cenderung jauh lebih panjang daripada durasi silabel on. (2) Sama dengan sinyal emosi kagum, pada emosi kesal ciri sinyal emosi pada interjeksi ondeh ditunjukkan oleh durasi silabe deh yang cenderung panjang. Namun, pada emosi kesal, penutur cenderung tidak mengucapkan bunyi [on] sehingga yang terdengar hanya bunyi [deh]. (3) Sinyal emosi kaget ditunjukkan dengan nada pada silabel on yang cenderung tinggi bila dibandingkan dengan silabel on pada emosi kagum dan kesal.

Tahap selanjutnya adalah tahap uji screeningyang dilakukan untuk memilih data suara terbaik, memiliki kejelasan, dan ketepatan sinyal emosi. Dalam penelitian ini tahap uji screening tidak melibatkan responden. Penulis sendiri yang melakukan uji screening terhadap data yang didapat. Penulis memilih satu dari tiga hasil manipulasi untuk setiap emosi. Penulis menggunakan intuisi penulis, yang juga merupakan penutur asli bahasa Minangkabau, untuk menilai mana data yang layak dijadikan sampel data. Berdasarkan hasil uji screening tersebut, penulis memilih tiga 
data bunyi yang dinilai memiliki kejelasan bunyi dan pola intonasi. Kode data dan sinyal sikap dan emosi yang dipilih adalah 0101, 0201, dan 0301.

Ketiga data kemudian melewati tahap eksperimen dan modifikasi kontur. Melalui grafik kontur dan deskripsinya dapat dilihat bahwa ada dua fitur pembeda antara interjeksi ondeh yang membawa ketiga sinyal emosi dimaksud. Fitur pembeda pertama adalah durasi silabe kedua deh yang panjang dari silabe pertama on. Perbedaan ini jelas membedakan antara sinyal emosi kagum dan kesal dengan emosi kaget. Alasannya adalah apabila terjadi perubahan pada durasi silabe deh itu, akan memberikan sinyal emosi yang berbeda. Memang pada emosi kagum dan kesal durasi deh sama-sama panjang, tetapi pada kaget silabe on cenderung tidak terdengar sehingga yang terdengar hanya bunyi [deh]. Alir nada yang ditunjukkan oleh kedua sinyal emosi juga berbeda.Oleh karena itu, durasi silabe deh perlu dimodifikasi dengan memperpanjang atau memperpendek durasi silabe deh itu.

Selanjutnya, tinggi nada silabe pertama on pada sinyal emosi kaget sebagai fitur pembeda kedua. Tinggi nada silabe on itu cukup signifikan karena apabila diubah akan menimbulkan keragu-raguan apakah ungkapan ondeh itu membawa emosi kaget atau tidak. Oleh karena itu, empat modifikasi kontur nada dibuat untuk emosi kaget dengan menaikkan atau menurunkan tinggi nada silabe on.

Dari hasil modifikasi kontur nada dan durasi didapat dua belas buah grafik kontur nada dan durasi. Untuk sinyalemosi kagum dan kesal modifikasi dilakukan dengan memperpanjang dan memperpendek durasi silabel kedua deh, sedangkan untuk sinyal sikap dan emosi kaget dengan menaikkan atau menurunkan frekuensi titik nada silabel deh. Grafik-grafik berikut berturut-turut adalah hasil modifikasi masing-masing sinyal emosi.

\section{Grafik 10 Hasil Modifikasi 0201 (Emosi Kagum)}

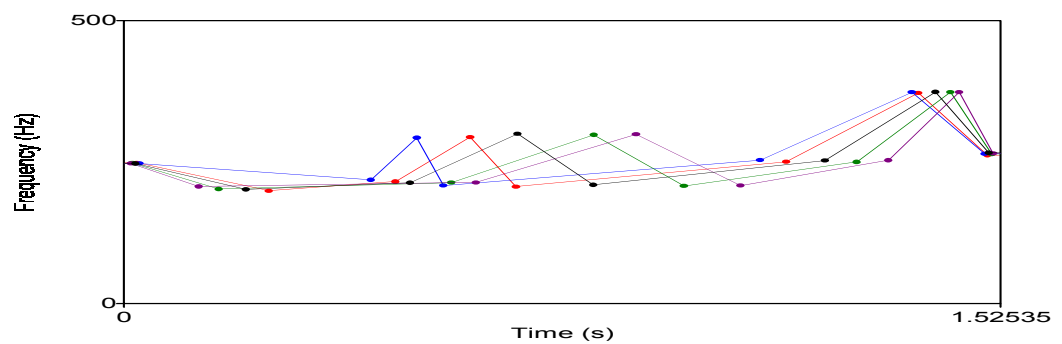

\section{Grafik 11 Hasil Modifikasi 0201 (Emosi Kaget)}




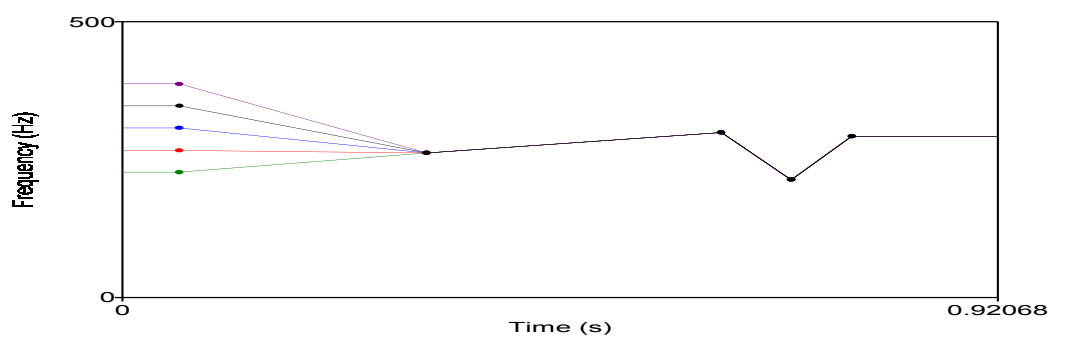

\section{Grafik 12 Hasil Modifikasi 0301 (Emosi Kesal)}

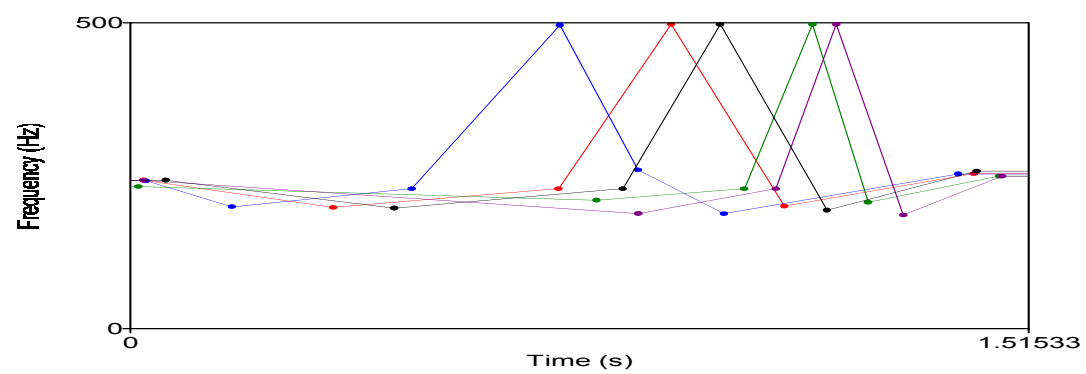

Setelah melewati tahap eksperimen dan modifikasi kontur, uji persepsi dapat dilakukan. Tahap ini dilakukan untuk dapat memperoleh deskripsi kontur nada standar untuk emosi kagum, kaget, dan kesal. Tiga orang responden dilibatkan dalam tahap ini. Responden yang dipilih merupakan penutur asli bahasa Minangkabau yang dinilai memiliki organ auditoris yang baik, dengan jenjang usia antara 17-32 tahun. Responden diminta untuk mengisi lembar uji persepsi yang berisi penilain responden terhadap bunyi yang mereka dengar, apakah menunjukkan emosi kaget, kagum, atau kesal. Kemudian responden menentukan tingkat kejelasan bunyi, mulai dari nilai 1, 2, dan nilai tertinggi 3. Rerata nilai kejelasan dilakukan dengan menjumlah seluruh nilai dibagi jumlah responden.

rerata nilai $=$ nilai responden $1+$ nilai responden $2+$ nilai responden 3 
Tabel 1 Rekapitulasi Hasil Uji Persepsi

\begin{tabular}{|c|c|c|c|c|c|c|}
\hline \multirow{2}{*}{ No } & \multirow{2}{*}{$\begin{array}{l}\text { Sinyal Sikap } \\
\text { dan Emosi }\end{array}$} & \multirow{2}{*}{ Kode } & \multicolumn{3}{|c|}{ Responden } & \multirow{2}{*}{$\begin{array}{c}\text { Rerata } \\
\text { Nilai }\end{array}$} \\
\hline & & & R-1 & R-2 & R-3 & \\
\hline \multirow{4}{*}{1} & \multirow{4}{*}{ kagum } & 1101 & 3 & 3 & 3 & 3 \\
\hline & & 1102 & 2 & 2 & 1 & 1.6 \\
\hline & & 1103 & 3 & 3 & 2 & 2.6 \\
\hline & & 1104 & 3 & 3 & 2 & 2.6 \\
\hline \multirow{4}{*}{2} & \multirow{4}{*}{ kaget } & 1201 & 1 & 1 & 1 & 1 \\
\hline & & 1202 & 2 & 2 & 1 & 1.6 \\
\hline & & 1203 & 2 & 1 & 1 & 1.3 \\
\hline & & 1204 & 3 & 2 & 2 & 2.3 \\
\hline \multirow{4}{*}{3} & \multirow{4}{*}{ kesal } & 1301 & 3 & 3 & 3 & 3 \\
\hline & & 1302 & 3 & 2 & 3 & 2.6 \\
\hline & & 1303 & 1 & 3 & 2 & 2 \\
\hline & & 1304 & 2 & 3 & 3 & 2.6 \\
\hline
\end{tabular}

\section{HASIL DAN PEMBAHASAN}

Dari tabel rekapitulasi hasil uji persepsi didapat nilai kejelasan, ketepatan dan kesesuaian bunyi ujaran. Nilai 1 diberikan pada data yang tidak berterima, nilai 2 diberikan pada data yang cukup berterima, dan nilai 3 untuk data yang berterima. Nilai tiga (nilai tertinggi) ditetapkan sebagai patokan kontur dan dapat disimpulkan sebagai standar untuk emosi tertentu. Dari hasil uji persepsi terlihat bahwa modifikasi 1101, 1204, dan 1301 yang memiliki nilai rerata tertinggi. Tetapi hanya bunyi 1101 dan 1301 yang bernilai tiga, sehingga kontur kedua sinyal emosi itu dapat dijadikan sebagai pola standar untuk sinyal emosi kagum dan kesal. Untuk emosi kaget, standar 
belum dapat ditetapkan karena rerata nilai hasil ui persepsi yang tidak mencapai nilai tiga.

Selain hasil di atas, dari hasil uji persepsi juga ditemukan bahwa responden cenderung sulit untuk membedakan interjeksi ondeh yang membawa sinyal sikap dan emosi kaget dan kesal. Ini terlihat pada lembar uji persepsi yang menunjukkan bahwa ketiga responden membuat kesalahan dengan memilih sinyal emosi kesal yang seharusnya adalah sinyal emosi kaget dan sebaliknya. Kenyataan itu berbeda dengan perkiran sebelumnya karena dari hasil rekaman awal justru bunyi ondeh yang membawa sinyal emosi kagum dan kesal yang memiliki persamaan kontur nada yaitu terlihat dari panjang durasi silabel deh dan alir nada kata ondeh secara keseluruhan. Hal ini terjadi karena hasil modifikasi sinyal emosi kesal yang dilakukan dengan memperpendek durasi silabel deh sehingga bunyi yang terdengar seperti ondeh pada kaget.

Dari hasil uji persepsi juga terlihat bahwa konteks kalimat juga sangat memengaruhi responden dalam menentukan sinyal sikap dan emosi tertentu. Responden mengalami keraguan dalam menentukan apakah konteks kalimat menyatakan sinyal emosi kaget atau kesal.

Pada sinyal emosi kagum tidak terjadi kesalahan. Setiap responden memilih dengan benar, hanya nilai kejelasan dari bunyi yang mereka pilih yang berbeda. Hal ini memungkinkan penentuan kontur standar untuk interjeksi ondeh pembawa sinyal emosi kagum adalah kontur 1101.

Kontur nada dan durasi standar untuk sinyal emosi kagum dan kesal tersaji dalam grafik di bawah ini

\section{Grafik 13 Kontur nada dan durasi standar untuk emosi kagum (1101)}

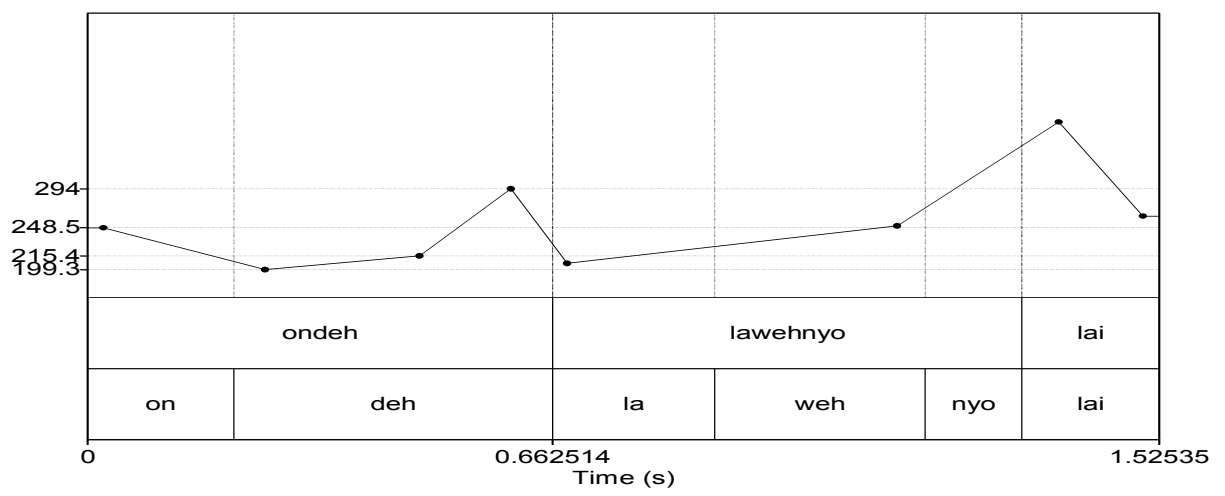

Pada grafik terlihat bahwa kontur standar untuk ondeh yang membawa sinyal kagum adalah durasi silabel deh sekitar $0.662514 \mathrm{~s}$ dan tinggi nada silabe pertama on 
adalah sekitar $248.5 \mathrm{~Hz}$. Terjadi penurunan tinggi nada pada silabel kedua deh sekitar 49.2 Hz, kemudian nada mencapai frekuensi maksimal pada bunyi [e] dengan kenaikan dari silabe kedua sekitar $94.7 \mathrm{~Hz}$.

\section{Grafik 14 Kontur nada dan durasi standar untuk emosi kesal (1301)}

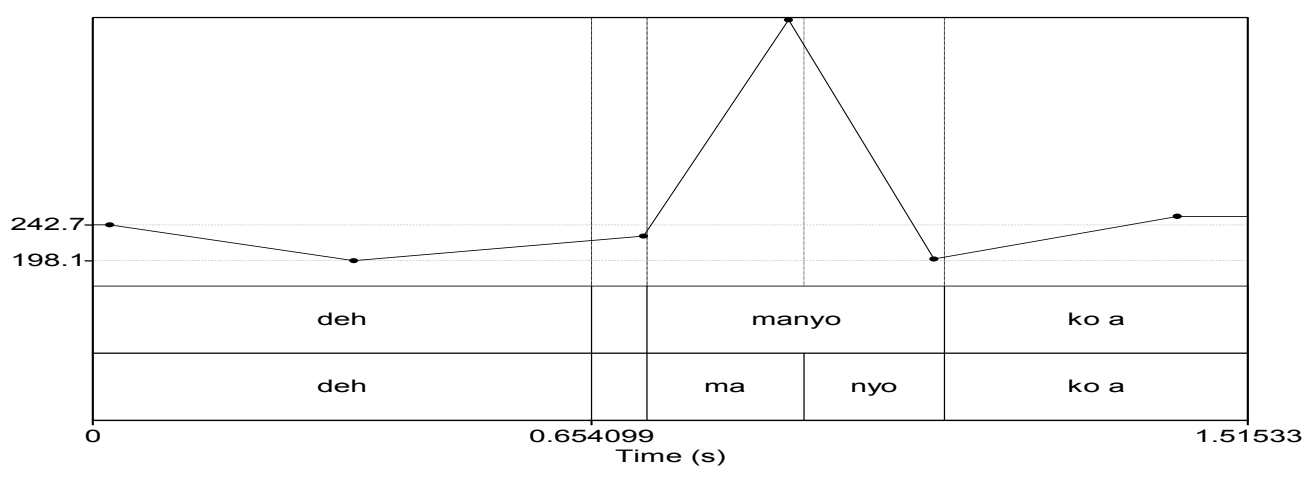

Kontur standar untuk interjeksi ondeh pembawa sinyal emosi kesal adalah dengan durasi deh sekitar 0.654099 s. Pada awal ujaran tinggi tinggi nada mencapai 242.7 Hz kemudian mengalami penurunan pada bunyi [e] sekitar $44.6 \mathrm{~Hz}$.

\section{SIMPULAN}

Berdasarkan pembahasan dapat disimpulkan sebagai berikut. Perasaan bahagia dan sedih diekspresikan dalam beragam cara, seperti pemilihan nosi, gerak dan mimik. Sinyal emosi tersebut dapat juga direpresentasikan melalui faktor fonetis yang mengikuti tuturan. Faktor yang dimaksud berkaitan dengan fitur prosodi tuturan. Fitur prosodi yang berpengaruh dalam sinyal tersebut adalah nada, intonasi, dan durasi. Apabila penutur dalam kondisi bahagia, nada yang dihasilkan cenderung lebih tinggi dan sebaliknya, apabila penutur dalam kondisi sedih/kecewa nada yang dihasilkan lebih rendah.

Salah satu ungkapan dalam bahasa Minang, yaitu ondeh memperlihatkan ciri-ciri interjeksi yaitu secara sintaksis tidak berhubungan dengan kata-kata lain di dalam ujaran, yang mengungkapkan perasaan pembicara, suatu reaksi sesaat yang merupakan dampak dari situasi ekstra-linguistik, dan umumnya terletak di awal ujaran. Ondeh dapat menggambarkan sikap dan emosi penutur melalui intonasi dan durasi ujaran. Dari hasil pengolahan dan penganalisisan data yang telah dilakukan dapat disimpulkan bahwa (1) Interjeksi ondeh dengan kontur intonasi tertentu membawa sinyal sikap dan emosi yang berbeda. Sinyal sikap dan emosi itu berupa perasaan kagum, kaget, dan kesal, (2) Interjeksi ondeh yang membawa sinyal emosi kagum memperlihatkan perbedaan durasi yang cukup signifikan antara silabe on dan deh. Durasi silabel deh cenderung jauh lebih panjang daripada durasi silabel on. Hal ini yang menjadi ciri interjeksi ondeh pembawa sinyal sikap dan emosi kagum jika 
dibandingkan dengan emosi kaget dan kesal, (3) Sama dengan sinyal emosi kagum, pada emosi kesal ciri sinyal emosi pada interjeksi ondeh ditunjukkan oleh durasi silabe deh yang cenderung panjang. Namun, pada emosi kesal penutur cenderung untuk tidak mengucapkan bunyi [on] sehingga yang terdengar hanya bunyi [deh]. (4) Sinyal emosi kaget ditunjukkan dengan nada pada silabel on yang cenderung tinggi bila dibandingkan dengan silabel on pada emosi kagum dan kesal. (5) Konteks kalimat juga sangat berpengaruh dalam menentukan sinyal sikap dan emosi tertentu. 


\section{DAFTAR PUSTAKA}

Crystal, David. 1997. A Dictionary of Linguistics and Phonetics. Edisi Keempat. Oxford: Blackwell Publisher.

Kridalaksana, Harimurti. 2008. Kamus Linguistik. Edisi Keempat. Jakarta: Gramedia Pustaka Umum.

Ladefoged. 2006. A Course in Phonetics. Edisi Kelima. Boston: Thomson.

Moussay, Gerard. 1998. Tata Bahasa Minangkabau. Terjemahan La Langue Minangkbau oleh Rahayu S. Hidayat. Jakata: Gramedia.

Rahyono, F.X. 2005. "Aspek Fisiologis Bahasa”. Dalam Kushartanti, Untung Yuwono, Multamia Lauder. Editor.Pesona Bahasa: Langkah Awal Memahami Linguistik. Jakarta: Gramedia.

Syafyahyadkk. 2015. "Watak Kato dalam Bahasa Minangkabau: Sebagai Cerminan Perilaku Berbahasa Masyarkat Minangbakabau". Dalam Arbitrer. Volume 2, Nomor 2, Halaman 13--27. Padang.

Waugh, Linda. R dan Schoonveld, C. H. Van, ed. 1980. The Melody of Language. Baltimore: University Park Press.

Witteman, Jurriaan. 2014. Towards a Cognitive Neuroscience of Prosody Perception and its Modulation by Alexithymia. Leiden: Leiden University. 